\title{
Late postoperative complications of arteriovenous fistula for hemodialysis
}

\author{
Zlatko Maksimovićn ${ }^{1,2,}$ \\ Nenad Lalović \\ Siniša Maksimović ${ }^{1,3}$ \\ 'Public Hospital Institution \\ "Sveti Vračevi" Bijeljina, \\ The Republic of Srpska, \\ Bosnia and Herzegovina \\ ${ }^{2}$ University of East Sarajevo, \\ Faculty of Medicine, Foca, \\ The Republic of Srpska, \\ Bosnia and Herzegovina \\ 3University of Banja Luka, \\ Faculty of Medicine, Banja Luka, \\ The Republic of Srpska, \\ Bosnia and Herzegovina
}

Received: 16/09/2020

Accepted: 26/03/2021

\section{Corresponding author: \\ Zlatko Maksimović, PhD, specialist in general surgery Srpske vojske 53, 76300 Bijeljina zlatko.maksimovic@gmail.com}

Copyright: @2021 Zlatko Maksimović et all. This is an Open Access article distributed under the terms of the Creative Commons Attribution 4.0 International (CC BY 4.0) license.

\section{Summary}

The vascular approach is a prerequisite for performing hemodialysis, but their "weak points" are different and frequent complications. Modern guidlines recommend native arteriovenous fistula (AVF) as the first choice of vascular approach, because it is characterized by the longest survival and the least complications compared to other vascular approaches. All complications of AVF can be divided into intraoperative, early, and late postoperative. This paper presents the late postoperative complications of AVF, their frequency, causes, diagnosis and treatment.

The most important late postoperative complications are: stenosis, thrombosis, aneurysm or pseudoaneurysm formation, infection, hand edema, hematoma, ischemic steal syndrome, ischemic neuropathy, congestive heart failure. Large differences in the frequency of each complication in earlier studies can be explained by differences in surgical technique, localization of AVF, diagnostic methods, but, above all, differences between the presented groups of patients. It is described that the age of patients, sex, underlying disease, the presence of comorbid conditions and various metabolic and immune disorders characteristic of chronic renal failure, as well as the way of using and caring for AVF significantly affect the occurrence of AVF complications. One of the main predictors of AVF success and survival is the quality of the patients' blood vessels, and therefore careful examination of blood vessels before approaching AVF creation is of particular importance.

The creation, use and care of AVF is the task of the team of health professionals who take part in the treatment of these patients, and successful treatment requires their good cooperation, as well as cooperation with patients.

Key words: arteriovenous fistula, hemodialysis, late complications, risk factors

\section{Introduction}

The number of patients with end-stage renal disease requiring treatment with renal replacement methods is steadily increasing. According to the Renal Registry of Bosnia and Herzegovina, during the period from 2002 to 2018, the number of patients treated with kidney replacement methods increased from 1,616 to 2,703, and at the same time in the Republic of 
Srpska the number of these patients doubled $(536-1,082)$ [1]. The largest percentage of patients with end-stage renal disease is treated with hemodialysis worldwide, even in Bosnia and Herzegovina, where in 2018, 2,238 (83\%) patients were treated with hemodialysis, and in $1,740(78 \%)$ of them the vascular approach was arteriovenous fistula (AVF).

The vascular approach is a prerequisite for performing hemodialysis, and modern guidlines recommend native arteriovenous fistula (AVF) as the first choice of the vascular approach, because it is characterized by the longest survival and the least complications compared to other types of vascular approach $[2,3]$. However, vascular approaches are the "weak point" of hemodialysis because all vascular approaches, including AVF, are associated with various complications. A number of studies have shown that about $30 \%$ of hospitalizations of patients on hemodialysis are necessary for the formation and/or solving the complications of vascular approaches. The costs of vascular approaches account for $14-20 \%$ of the total costs of treating hemodialysis patients [4]. In addition, AVF complications are associated with increased morbidity and mortality, and prevention, early detection, and forehand and adequate treatment of complications can significantly reduce the number and duration of hospitalizations, other serious complications, and mortality $[2,5,6]$.

As most patients with end-stage renal disease in our country are treated with hemodialysis, special attention should be paid to the formation of AVF, their care, and especially to the prevention and treatment of the complications. All complications of AVF can be divided into intraoperative and postoperative, and the latter can be early and late. This paper is presenting late postoperative complications of AVF, their frequency, causes, diagnosis, and treatment.

The most important late postoperative complications are: stenosis, thrombosis, inadequate flow through the fistula, aneurysm or pseudoaneurysm formation, infection, hand edema, hematoma, ischemic steal syndrome, ischemic neuropathy, congestive heart failure. In some of the examined groups not all of them are registered. Data on the prevalence of some late complications of AVF are very different, as illustrated by Table 1, which shows the data of several groups of authors. Aljuaid et al. [6] cite ischemic neuropathy (29.6\%) and AVF aneurysms $(25 \%)$ as the most common complications, and the last in several studies account for over $45 \%$ of all complications [8-10]. On the other hand, in a study by Greenberg et al. [11] AVF stenosis was most commonly registered (51.4\%). The data of Schinstock et al. [12] who describe bleeding (33\%) and AVF infection $(26.8 \%)$ as the most common complications of AVF, are completely different. While bleeding, hematomas, and edema are not reported in most studies, there are studies in which the percentage of patients with these complications is not negligible $[13,14]$. In our prospective study, which included 250 patients, thrombosis and inadequate flow

Table 1. Incidence of late postoperative complications

\begin{tabular}{lcc}
\hline \multicolumn{1}{c}{ Complication } & $\begin{array}{c}\text { In studies by } \\
\text { other authors } \\
{[4,6-14]}\end{array}$ & $\begin{array}{c}\text { In the study by } \\
\text { Z. Maksimović } \\
{[15]}\end{array}$ \\
\hline $\begin{array}{l}\text { Stenosis } \\
\text { Thrombosis }\end{array}$ & $\begin{array}{l}14-51.4 \\
\text { Aneurysm and }\end{array}$ & 27.4 \\
pseudoaneurysm & $3.8-60$ & 1.2 \\
$\begin{array}{l}\text { Heart failure } \\
\begin{array}{l}\text { Ischemic neurop- } \\
\text { athy }\end{array}\end{array}$ & $12-17$ & \\
$\begin{array}{l}\text { Infection } \\
\text { Bleeding }\end{array}$ & $2-4.423 .8$ & 4.1 \\
„Steal“ syndrome & $1.1-8$ & 4.1 \\
$\begin{array}{l}\text { Edema } \\
\text { Inadequate flow } \\
\text { through AVF }\end{array}$ & $1.5-3.7$ & 23.3 \\
Haematoma & & 24.7 \\
\hline
\end{tabular}

AVF - arteriovenous fistula 
through AVF are the most common complications [15]. Differences in the frequency of each complication can be explained by differences in surgical technique, AVF localization, diagnostic methods, but, above all, differences in the characteristics of patients and the quality of their blood vessels. It has been described that the age of patients, sex, underlying disease, comorbidities, but also the use and care of AVF significantly affect the occurrence of complications and survival of AVF $[4,8,16]$.

\section{Characteristics of late postoperative complications of arteriovenous fistula for hemodialysis}

Stenosis. The basis of stenosis is the process of neointimal hyperplasia that occurs in the venous part of the AVF in response to endothelial cell injury. This injury can occur during surgery, AVF puncture, due to altered hemodynamic forces, effects of uremic toxins $[17,18]$. Damaged endothelial cells produce inflammatory mediators that activate platelet aggregation and attract leukocytes to the damaged site. At the same time, activated endothelial cells increase the expression of growth factors that stimulate the migration of smooth muscle cells from the medium into the intima, their proliferation and the deposition of the extracellular matrix. All this leads to the formation of neointimal hyperplasia, a fibromuscular thickening of the blood vessel wall $[18,19]$. The frequency of stenosis greatly varies in published studies, which is due among other things to the different diagnostic procedures used to diagnose it. In our prospective study conducted in the period from 2002 to 2010 there was no possibility to diagnose AVF stenosis, but it could be assumed that among patients with inadequate flow through AVF, a large percentage had stenosis, which was confirmed in 15 patients during reintervention [15]. Clinically significant stenosis should always be suspected when the flow through the fistula is reduced, but also when there are problems with puncture, prolonged post-hemodialysis bleeding, pain in the fistula, longer maintenance of hand swelling, increased venous pressure. Doppler ultrasound is used to diagnose stenosis, and peak systolic velocity greater than $400 \mathrm{~cm} / \mathrm{sec}$ indicates the presence of stenosis. In addition, a flow drop of $20-25 \%$ per month is considered as an indicator of stenosis. The sensitivity of the ultrasound examination to detect significant stenosis ranges between $76-87 \%$. Angiography is a reliable method for determining AVF stenosis, but it is a more expensive and invasive method and requires the use of contrast [4]. Treatment of stenosis includes balloon dilation, stent implantation, or surgical revision [19].

Thrombosis. Virchow in his concept of the pathogenesis of thrombosis has listed three basic pathogenetic factors: vessel wall injury, changes in blood flow, and blood disorders. Although established more than $\mathbf{1 5 0}$ years ago, this concept can still be applied today to venous thrombosis and even to AVF thrombosis [20].

Damaged blood vessel wall and exposure of subendothelial structures to blood flow lead to platelet adhesion, which then secrete thromboxane A2 and adenosine diphosphate, stimulators of further adhesion. At the same time, "naked" collagen and released tissue thromboplastin start a coagulation cascade, and the key product of this cascade, thrombin and fibrinogen, form a thrombus [18].

In addition to neointimal hyperplasia, which is the main cause of stenosis and consequent thrombosis, many other disorders in chronic renal failure contribute to the development of thrombosis. While renal failure is characterized by decreased platelet function, hemodialysis patients are characterized by a prothrombotic condition. Chronic renal failure is accompanied by chronic inflammation, and CRP and other acute phase proteins are risk factors for AVF thrombosis. In addition, hyperhomocysteinemia, hypoalbuminemia, and hyperlipidemia also contribute to this prothrombotic 
condition. Artificial membranes and systems through which blood flows during hemodialysis activate platelets and start the coagulation cascade $[4,20]$.

Thrombosis is one of the main causes of the loss of AVF function resulting in missed dialysis sessions, hospitalization of patients, placement of temporary dialysis catheters, and accompanying complications. AVF thrombosis accounts for between 14.6 and $45 \%$ of complications observed in various studies [6-14], and in our group it is the most common complication and accounts for $27.4 \%$ of all late AVF complications [15]. The appearance of pain in the AVF area, palpation of the thrombus in the AVF and the loss of the "trill" above the AVF indicate thrombosis.

Various therapeutic methods for resolving thrombosis have been described, but it is of particular importance that treatment of thrombosis starts as early as possible. Today, various percutaneous methods of recanalization of vascular approaches for hemodialysis are used as alternatives to surgical thrombectomy, either using different thrombolytic drugs (urokinase, tissue plasminogen activator) alone or in combination with mechanical thrombectomy devices (Figure 1) $[19,21,22]$. One third of the patients in our series underwent thrombectomy, and those were patients who underwent

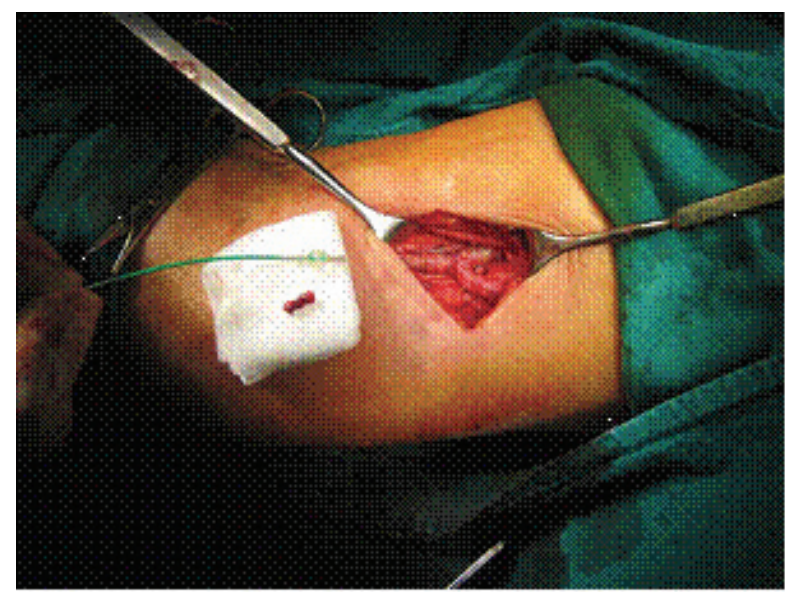

Figure 1. Thrombosis of the proximal radio-cephalic arteriovenous fistula. Thrombectomy with Fogarty catheter and new anastomosis surgery in the first 24 hours after the observed thrombosis, while in the others a new vascular approach had to be performed.

Aneurysms and pseudoaneurysms. An aneurysm is a pathological enlargement of the blood vessel wall that can occur on anastomoses or at the sites of a weakened venous wall due to repeated punctures and replacement of the blood vessel wall with fibrous tissue (Figures 2. and 3). Jankovic et al. [10] describe that there is a higher risk of developing aneurysm in patients with adult polycystic kidney disease, as well as in those who dialyze longer with high-flow membranes and high blood flow. The formation of aneurysms

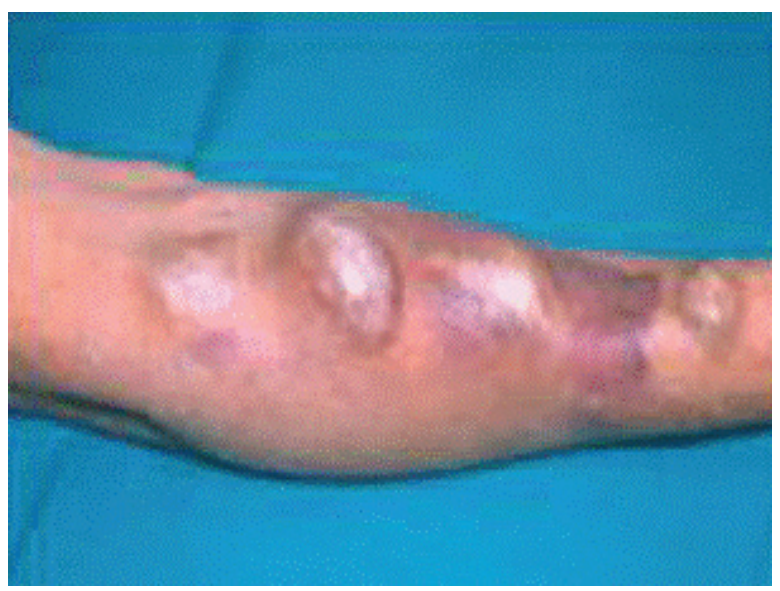

Figure 2. Aneurysms at puncture sites

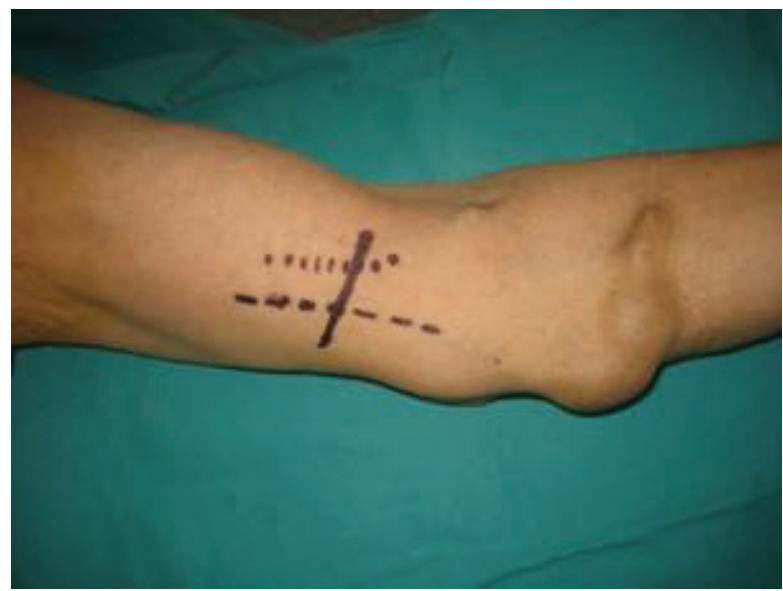

Figure 3. Several years duration dialysis via forearm AVF. Thrombosis of all aneurysmically dilated veins. Ultrasound confirmed the possibility of secondary AVF transposition of the basilic vein above the upper arm 


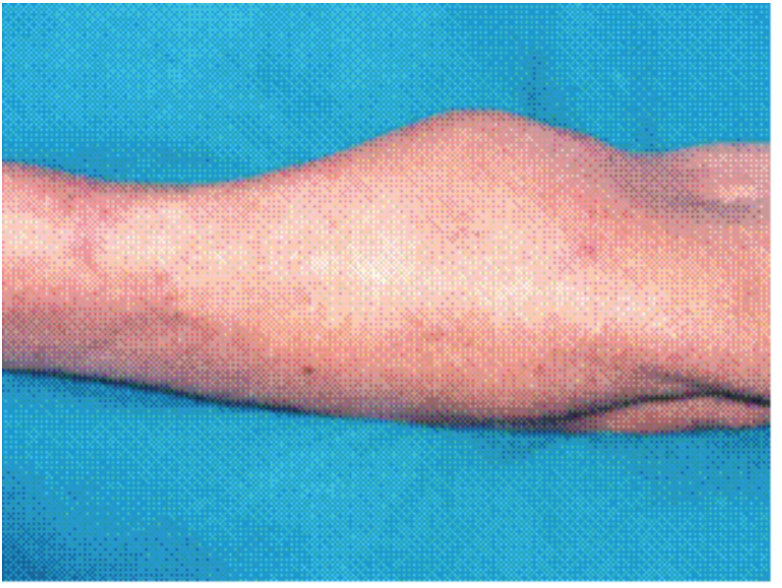

Figure 4. Pseudoaneurysm with chronic course

and pseudoaneurysms can be prevented by regular controls of the vascular approach, the quality of the skin above it with the obligatory change of the puncture site, especially in patients with an increased risk of aneurysm formation $[18,23]$.

In the studies published so far, there are huge differences in the frequency of AVF aneurysm. In some, aneurysm is the most common complication and accounts for about half of all AVF complications [8-10]. A slightly lower percentage of aneurysms are reported by Al-Thani et al. (32\%) [24], while Greenberg et al. [11] describe an aneurysm as one of the rarest complications $(3.8 \%)$. The occurrence of pseudo or true aneurysm was detected in our series in only three patients [15]. Such formations are more accurately diagnosed by color Doppler ultrasound examination, which can differentiate pseudoaneurysmal from aneurysmal enlargement, and on the basis of which a decision can be made about possible surgical correction (Figures 4 . and 5).

Aneurysms and pseudoaneurysms can cause thromboembolism, local ischemia and skin necrosis, compression of surrounding nerves and paresthesia, fistula thrombosis, infection and sepsis, and can lead to rupture and severe bleeding during hemodialysis and also at home when it is dangerous for life $[18,24]$. The National Kidney Foundation's

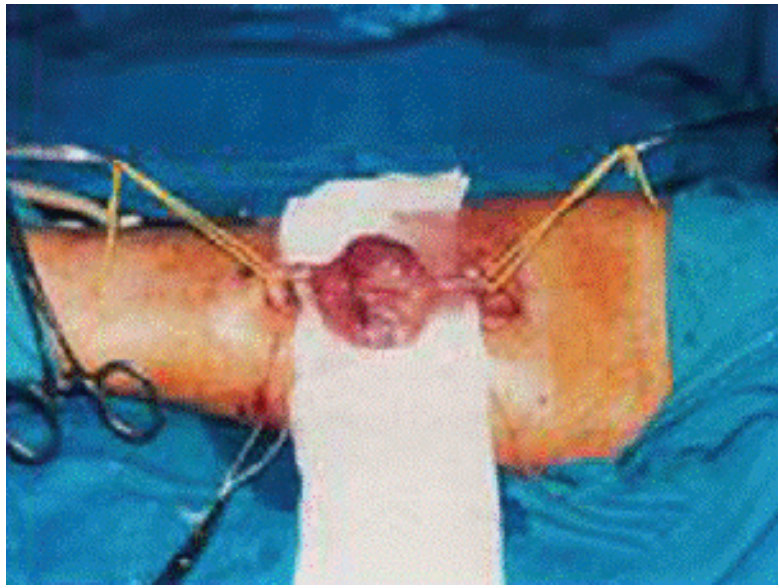

Figure 5. Surgical extirpation of the aneurysm with continued dialysis on the same arteriovenous fistula

Kidney Disease Outcomes Quality Initiative (K/DOQI) guide recommends that we do not use an aneurysmally altered part of AVF, to avoid it for puncture [3]. The aneurysm can be marked on the skin with ultrasound as a place to avoid puncture, and a usable part of the AVF can be marked on the skin with a felttip pen. In this way, the lifespan of the fistula is extended and reintervention is delayed, i.e. the formation of a new fistula at the proximal level. Surgery is indicated if an enlargement of the aneurysm is observed or if there is a pronounced stenosis of the AVF, in the case of a sudden increase in the aneurysm, the appearance of thinned skin, lack of puncture or rupture site $[3,15,18]$. One of our patients with pseudoaneurysm underwent surgery due to bleeding, while the other two avoided puncture in the pseudoaneurysm section.

Isolated AVF infection is a rare complication. Bylsma et al. [25] in an extensive meta-analysis that included 318 studies and 62,712 vascular approaches have shown that the risk of AVF infection is $4.1 \%$, or 0.018 per 100 days of AVF.

Most often, AVF-related infection is only perivascular cellulitis, which is manifested by signs of inflammation (localized redness, swelling and pain) [26]. However, systemic bacteremia may develop, accompanied by malaise, fever, back pain, sometimes altered 
state of consciousness, unexplained hypotension, leukocytosis. Infection can be associated with other complications of AVF such as aneurysms or hematomas and then it is a much more serious complication [7].

The most important measure to prevent AVF infection is to follow the rules of asepsis and antisepsis. If there are local signs of infection in the area around the AVF, you should take a swab, but be sure to look for hematogenous spread of the infection (blood culture, ultrasound examination of the heart valves). Infectious complications of AVF are resolved with systemic antibiotic therapy based on the results of swabs and blood culture, and, if necessary, some of the surgical procedures. Antibiotics are administered orally for two weeks if there is no bacteremia and fever, and according to modern guidelines in case of fever and bacteremia antibiotics are administered intravenously also for two weeks [22], although many authors still recommend antibiotic therapy in these cases for $4-6$ weeks $[7,15,18]$. More extensive local signs of infection as well as larger hematomas or abscesses require classic surgical revision with postoperative drainage. AVF ligation is necessary only when it becomes a source of recurrent septic pulmonary embolism $[22,26]$.

Heart failure. Although there is a traditional opinion that AVF has a negative effect on heart function, the real role of vascular approaches for hemodialysis in the development of heart failure is still unclear today. While some authors state that only AVF in which the flow exceeds $2,000 \mathrm{ml}$ can lead to left ventricular hypertrophy and heart failure, others believe that AVF can cause heart failure only in patients with previous heart diseases [4,27-29]. However, even the most recent international guidlines do not provide a definition of high flow through vascular approaches or recommendations for fistula interventions that should be taken to prevent heart failure $[3,22,28]$.
The mechanism by which AVF can lead to heart failure has not yet been fully explained. There is an opinion that there is a significant correlation between the flow through the fistula and the cardiac index (minute volume of the heart per unit of body surface area) and that the cardiac index increases immediately after the AVF formation. The AVF formation is thought to increase the minute volume by $15 \%$ and left ventricular end-diastolic pressure by $4 \%$ [3,22]. Basile et al. [29], however, prove that the relationship between flow through the AVF and cardiac index is complex and that the increase in the flow through the AVF does not follow a linear increase in cardiac index. They explain this by the existence of a functional reserve of the myocardium and the possibility of the heart adapting to the increase in flow through the AVF, which also prevents the occurrence of heart failure. However, this only applies to flow through the fistula between 950 and 2,200 $\mathrm{ml} / \mathrm{min}$, while blood flow through the vascular approach above this value is a significant predictor of heart failure with a sensitivity of $89 \%$ and a specificity of $100 \%$ [29]. Investigating the relationship between flow through the AVF and minute volume, Zamboli et al. [28] show that already flow through vascular approach $\geq 603 \mathrm{ml} / \mathrm{min} / \mathrm{m} 2.7$ is associated with an increased risk of heart failure, especially in patients who already have some echocardiographic signs of heart damage.

In patients with heart failure and high flow through the AVF, it is necessary to check the existence of other possible causes of heart failure before the intervention that would reduce the flow: anemia, hypertension, poorly assessed dry weight and consequent hypervolemia. Only when these problems are solved, and the signs of heart failure do not decrease, the correction of AVF is proposed. Several surgical techniques are used to reduce high blood flow through the AVF to treat heart failure: caliber reduction of the AVF anastomosis, graft interposition, placement of circumferential 
polytetrafluoroethylene tape next to the anastomotic artery to reduce blood flow, or placement of a clip on the venous portion of the anastomosis to increase resistance as well as AVF ligation [27].

Limb ischemia induced by vascular approach. Limb ischemia, also known as blood theft syndrome or ischemic steal syndrome, occurs due to the retrograde flow of blood from an artery to a vein, which can cause ischemia distal to the anastomosis. There is an increased risk of developing this syndrome in patients with diabetes, people with atherosclerosis and peripheral vascular disease, the elderly and smokers [7]. Limb ischemia usually accounts for less than $10 \%$ of all AVF complications, and according to meta-analysis by Al-Jashi et al. [30], the incidence of this syndrome is $0.05 / 1000$ patient days. The frequency is higher when A brachialis is used to create a vascular approach, and significantly less in radiocephalic AVF [18].

The clinical picture depends on the severity of the ischemia. Mild ischemia may be asymptomatic until the compensatory mechanisms of perfusion maintenance are exhausted, and then the patient complains of a feeling of coldness, pain, and the skin becomes pale or livid. Limb necrosis and ulceration occur in severe ischemia. Severe ischemia is an in- dication for closing the vascular approach, although reconstructive vascular operations are increasingly used [14, 18]. In a patient who developed hand ischemia after the formation of a brachiobasilic arteriovenous fistula (Figure 6), the pain stopped immediately after ligation of the fistula and the signs of ischemia soon disappeared.

Ischemic neuropathy is one of the rarer complications that accompany the AVF formation, which occurs as a consequence of ischemia. Most of the papers state that its frequency is between $1 \%$ and $10 \%$ [7], but a significantly higher percentage has also been described [6]. It is more common in patients with diabetes and already pronounced macroangiopathy, especially when the brachial artery is used to create AVF. Ischemic neuropathy of the upper extremities was first described by Bolton et al. [31], and the name "ischemic monomelic neuropathy" was introduced by Wilbourn [32], to point out that this is an isolated neuropathy due to reduced arterial blood supply of one extremity (from the Greek word melos - extremity) which should be distinguished from multiple neuropathy. There is also the opinion that ischemic neuropathy is a consequence of ischemic steal syndrome and only one of the clinical manifestations of that syndrome [33].



Figure 6. Ischemia of the hand occurring after the formation of a brachiobasilic arteriovenous fistula with transposition of the basilic vein 
It is manifested by severe pain, paresthesias, and weakness of the arm. Neurological examination determines the weakness of the group of muscles innervated by $n$. medianus and sensory defect in the region of the nerve innervation. Although the diagnosis is usually made clinically, electromyography and measurement of nerve conduction velocity can be used to confirm the diagnosis $[3,34]$.

Treatment of ischemic neuropathy aims to reduce blood flow to the vascular approach and increase limb perfusion distal to it. The AVF ligation, bandaging or angioplasty may be used for that purpose. Closure of functional AVF due to ischemic neuropathy should be carefully considered, as symptoms often persist or decrease only slightly after it [34]. However, it is thought that early closure of the vascular approach may lead to complete or partial recovery of the sensory and motor defect [33].

Other late complications of AVF, edema, bleeding, hematoma, are not mentioned in many papers. Edema is more common in brachiocephalic AVF and it is sometimes associated with wound infection. It is usually reduced by elevation of the arm, and it is very rarely necessary to ligate AVF due to edema [13]. Edema of the arms of our patients was mild and was treated conservatively in cooperation with specialists in internal and physical medicine [15]. Bleeding occurs more often as an early complication, and less often in the late postoperative period. It can occur due to overdose of heparin, damaged blood vessel wall during puncture, it can cause the formation of hematomas, and it rarely occurs due to rupture of the fistula $[13,14]$. Two of our patients with hematoma developed pseudoaneurysm, so one patient underwent reintervention due to bleeding. Most of our patients with hematoma were treated conservatively. More extensive hematomas can be resolved by ultrasound-guided aspiration, and less frequently classic surgical revision with postoperative drainage is required [15].

\section{Risk factors}

A number of factors are associated with the occurrence of AVF complications, and in the previous text, factors that may contribute to the occurrence of certain late postoperative complications have already been mentioned. Many of them act simultaneously and can jeopardize fistula function. As knowledge of risk factors for complications and AVF survival is very important for defining measures that can prevent complications, a large number of papers have been dedicated to their research.

Large differences in the frequency of complications in some studies also indicate differences in the frequency of some risk factors. In addition to demographic characteristics of patients, the occurrence of certain complications depends on the underlying kidney disease, the presence of comorbid conditions or various metabolic and immune disorders that occur in chronic renal failure and have already been mentioned in the pathogenesis of AVF stenosis and thrombosis [7,8,28]. Recently, Gardeezi et al. [35] have shown that low concentration of $25(\mathrm{OH}) \mathrm{D}$ and high concentration of FGF-23 and parathormone were associated with a higher risk for AVF reinterventions. Mineral metabolism disorder in chronic renal failure and its association with cardiovascular diseases are well known, but little is known about the impact of these disorders on AVF function [36,37].

One of the main predictors of AVF success and survival is the quality of patients' blood vessels $[6,15]$ and therefore the importance of careful examination of blood vessels before approaching AVF creation is emphasized. In recent years, more precise preoperative procedures have been introduced to assess the quality of blood vessels. The KDOQI guidelines provide clear recommendations on when and how to perform vessel mapping before approaching the creation of a vascular approach [3]. Donfrid et al. [38] based on their extensive experience, point out that in the preoperative 


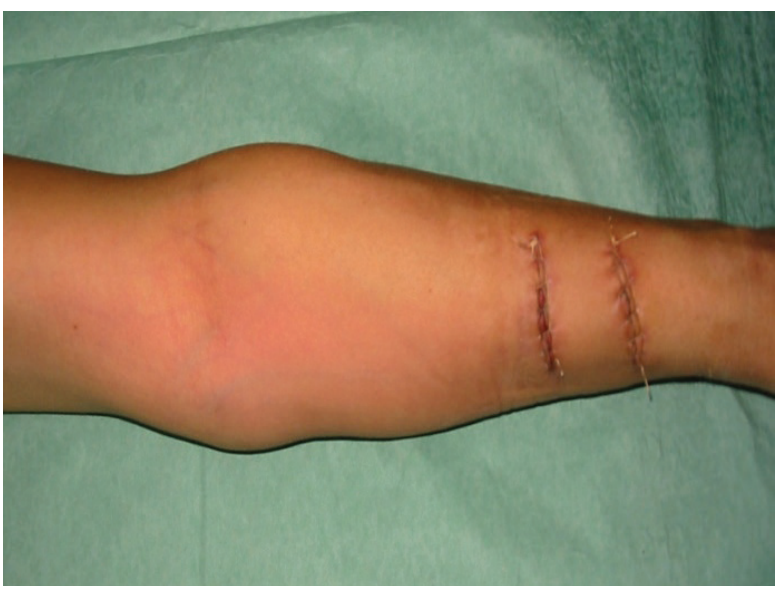

Figure 7. Without ultrasound diagnostics, AVF operation failed twice in one day

diagnosis, a vascular approach requires an exhaustive anamnesis and clinical examination, and that vitium artis is not to perform an ultrasound examination (Color Doppler sonography) of blood vessels in both arms (Figure 7. and 8). A well-planned AVF and performed on a prepared patient using all the necessary diagnostics with a well-educated vascular surgeon are a guarantee of a successful creation of a vascular approach. It is a big mistake that the first vascular approach is performed by a poorly-educated surgeon. The failure of the first approach is an introduction to later difficult-to-resolve complications (Figure 9) [38].

Of great importance for the occurrence of complications of AVF is the way of their use, and especially it is necessary to avoid premature puncture of AVF after surgery, repeated punctures in the same place, excessive compression. Examining the factors associated with the loss of AVF patency, we have previously shown that hypotension, diabetes, anemia, previous venous cannulation used for AVF, artery and vein quality, use of AVF for hemodialysis less than 45 days after its creation, number of intraoperative and postoperative complications, are significant independent risk factors for loss of AVF patency [16]. In addition to all these factors, we and many other authors emphasize the impor-



Figure 8. Color Doppler showed possible AVF of the cubital region after which a successful AVF was done

tance of surgical technique and only strict adherence to all recommended details of AVF surgery can ensure the optimal result of the procedure $[6,7,16,38-40]$.

Most of chronic kidney diseases are progressive and end in end-stage renal disease. Therefore, we should draw the attention of all those who treat patients with chronic kidney diseases, as well as of the patients themselves, that keeping blood vessels from the initial stages of the disease is extremely important for the later successful creation of AVF and its functioning.

\section{Conclusion}

Functional AVF is a prerequisite for successful hemodialysis, but frequent complications of AVF are still one of the most common causes of hospitalization of patients treated with hemodialysis. Knowledge of the etiopathogenesis and all risk factors for the occurrence of AVF complications enables their prevention, early detection and timely and adequate treatment. AVF creation, usage and care are a continuous task of a team of health professionals (nephrologists, surgeons, radiologists, nurses, etc.) who need to achieve good cooperation with patients, which only enables successful treatment. 
Gratitude. The authors express their exceptional gratitude to Branko Donfried, $\mathrm{PhD}$, an honorary member of the Academy of Medical Sciences SLD, on the original photographs from his large collection with which he enriched this work. Thanks also to Ljubica Djukanović, PhD on useful remarks and pieces of advice during the preparation of the paper.

Funding source. The authors received no specific funding for this work.

Ethical approval. This article does not contain any studies with human participants performed by any of the authors.
Conflicts of interest. The authors declare no conflict of interest.
References:

1. Association of doctors for nephrology, dialysis and kidney transplantation in $\mathrm{BiH}$. Renal Registry of Bosnia and Herzegovina. Avaiable from: https://undt.ba/registar/godisnji-izvjestaji July 20, 2020.

2. Lok CE, Foley R. Vascular access morbidity and mortality: trends of the last decade. Clin J Am Soc Nephrol 2013;8:1213-9.

3. NKF-KDOQI. Clinical practice guidelines for vascular access. Am J Kidney Dis 2006;48(1):S248-S272.

4. Stolić R. Chronic complications of arteriovenous fistula for hemodialysis. In: Donfrid B, Dimković N, editors. Secondary vascular approaches for hemodialysis. Monographs of scientific conferences AMN SLD 2010;3(1):101-18.

5. Ravani P, Palmer SC, Oliver MJ, Quinn RR, MacRae JM, Tai DJ, et al. Associations between hemodialysis access type andclinical outcomes: A systematic review. J Am Soc Nephrol 2013;24:465-73.

6. Aljuaid MM, Alzahrani NN, Alshehri A, ALkhaldi LH, Alosaimi FS, Aljuaid NW, et al. Complications of arteriovenous fistula in dialysis patients: Incidence and risk factors in Taif city, KSA. J Family Med Prim Care 2020;9(1):407-11.
7. Stolic R. Most Important Chronic Complications of Arteriovenous Fistulas for Hemodialysis Med Princ Pract 2013;22:220-8.

8. Cavallaro G, Taranto F, Cavallaro E, Quatra F. Vascularcomplications of native arterio - venous fistulas forhemodialysis: Role of microsurgery. Microsurgery 2000;20:252-4.

9. Derakhshanfar A, Gholyaf M, Niayesh A, Bahiraii S. Assessment of Frequency of Complications of Arterio-Venous Fistula in Patients on Dialysis: A Two-Year Single Center Study from Iran. Saudi J Kidney Dis Transpl 2009;20(5):872-5.

10. Jankovic A, Donfrid B, Adam J, Ilic M, Djuric $\mathrm{Z}$, Damjanovic T, et al. Arteriovenous fistula aneurysm in patients on regular hemodialysis: prevalence and risk factors. Nephron Clin Pract 2013;124(1-2):94-8.

11. Greenberg J, Jayarajan S, Reddy S, Schmieder FA, Roberts AB, van Bemmelen PS, et al.LongTerm Outcomes of Fistula First Initiative in an Urban University Hospital - Is It Still Relevant? Vasc Endovascular Surg 2017;51(3):125-30.

12. Schinstock CA, Albright RC, Williams AW, Dillon JJ, Bergstralh EJ, Jenson BM, et al. Outcomes of arteriovenous fistula creation after the Fistula First Initiative. Clin J Am Soc Nephrol 2011;6(8):1996-2002. 
13. Dix FP, Khan Y, Al-Khaffaf H. The brachial artery-basilic veinarterio-venous fistula in vascular access for haemodialysis - areview paper. Eur J Vasc Endovasc Surg 2006;31: 70-9.

14. Thabet BA, Ewas MO, Hassan HA, Kamel MN. Complications of arteriovenous fistula in dialysis patients at Assiut University Hospital. J Curr Med Res Pract 2017;2:119-24.

15. Maksimović Z. Prognostic factors of early and late patency of native hemodialysis arteriovenous fistulas. Doctoral thesis. University of Belgrade, Faculty of Medicine, 2011.

16. Maksimović Z, Tasić N, Maksimović S, Gavrić N. Factors associated with loss of patency of arteriovenous fistula for hemodialysis. Biomedical Research 2018;9(1):46-55.

17. Remuzzi A, Ene-Iordache B. Novel paradigms for dialysis vascular access: Upstream hemodynamics and vascular remodeling in dialysis access stenosis. Clin J Am Soc Nephrol 2013;29:1-8.

18. Janković A, Donfrid B, Dimković N. Najčešće komplikacije vaskularnih pristupa za hemodijalizu. U: Donfrid B, Dimković N, urednici. Sekundarni vaskularni pristupi za hemodijalizu. Monografije naučnih skupova AMN SLD 2018;8(2):101-19.

19. Quencer KB, Oklu R. Hemodialysis access thrombosia. Cardiovasc Diagn Ther 2017;7(3):S299S308.

20. Mammen EF. Pathogenesis of venous thrombosis. Chest 1992;102:640S-644S.

21. MacRae JM, Dipchand C, Oliver M, Moist L, Lok C, Clark E, et al. Arteriovenous Access Failure, Stenosis and Thrombosis. Can J Kidney Health Dis 2016,(3):1-10.

22. Tordoir J, Canaud B, Haage P, Konner K, Basci A, Fouque D, et al. EBPG on Vascular Access. Nephrol Dial Transplant 2007;22(2):88-117.

23. Wang A, Silberzweig JE. Brachial Artery Pseudoaneurysms Caused by Inadvertent Hemodialysis Access Needle Punctures. Amer J of Kidney Dis 2009;53(2):351-4.

24. Al-Thani H, El-Menyar A, Al-Thani N, Asim M, Hussein A, Sadek A, Sharaf A, Fares A. Characteristics, Management, and Outcomes of Surgically Treated Arteriovenous Fistula Aneurysm in Patients on Regular Hemodialysis. Ann Vasc Surg 2017;41:46-55.
25. Bylsma LC, Gage SM, Reichert H, Dahl SLM, Lawson JH.Arteriovenous Fistulae for Haemodialysis: A Systematic Review and Metaanalysisof Efficacy and Safety Outcomes. Eur J Vasc Endovasc Surg 2017;54(4):513-22.

26. Kumbar L, Yee J. Current Concepts in Hemodialysis Vascular Access Infections. Adv Chronic Kidney Dis 2019;26(1):16-22.

27. Basile C, Lomonte C. When and how should an arteriovenousaccess be modified because of a high blood flow rate? Semin Dial 2011;24:396-98.

28. Zamboli P, Lucà S, Borrelli S, Garofalo C, Liberti ME, Pacilio M, Lucà S, Palladino G, Punzi M. High-flow arteriovenous fistula and heart failure: could the indexation of blood flow rate and echocardiography have a role in the identification of patients at higher risk? J Nephrol 2018;31(6):975-83.

29. Basile C, Lomonte C, Vernaglione L, Casucci F, Antonelli M, Losurdo N. The relationship between the flow of arteriovenous fistula and cardiac output in haemodialysis patients. Nephrol Dial Transpl 2008;23:282-7.

30. Al-Jashi AA, Liz AR, Lok, ChE, Zhang JC, Mois LM. Complications of the Arteriovenous Fistula: A Systematic Review. J Am Soc Nephrol 2017;28:1839-50.

31. Bolton CF, Driedger AA, Lindsay RM. Ischaemic neuropathy in uraemic patients caused by bovine arteriovenous shunt. J Neurol Neurosurg Psychiatry 1979;42:810-4.

32. Wilbourn AJ, Furlan AJ, Hulley W, Ruschhaupt W. Ischemicmonomelic neuropathy. Neurology 1983;33:447-51.

33. Datta S, Mahal S, Govindarajan R. Ischemic Monomelic Neuropathy after Arteriovenous Fistula Surgery: Clinical Features, Electrodiagnostic Findings, and Treatment. Cureus 2019;11(7):e5191.

34. Thimmisetty RK, Pedavally S, Rossi NF, Fernandes JAM, Fixley J. Ischemic monomelic neuropathy: diagnosis, pathophysiology, and management. Kidney Int Rep 2017;2:76-9.

35. Gardezi AI, Karim MS, Rosenberg JE, Scialla JJ, Banerjee T, Powe NR, et al. Markers of mineral metabolism and vascular access complications: The Choices for Healthy Outcomes in Caring for ESRD (CHOICE) study. Hemodial Int 2020;24(1):43-51. 
36. Jankovic A, Damjanovic T, Djuric Z, Marinkovic J, Schlieper G, Djuric P, et al. Calcification in arteriovenous fistula blood vessels may predict arteriovenous fistula failure: a 5-year follow-up study. Int Urol Nephrol 2017;49(5):881-7.

37. Walker J, Hiramoto J, Gasper W, AuyangP, Conte MS, Rapp JH, et al. Vitamin D deficiencyis associated with mortality and adverse vascularaccess outcomes in patients with end stage renal disease. J Vasc Surg 2014;60:176-83.

38. Donfrid B, Lozanče O, Stefanović Z, Dimković N. Sekundarni vaskularni pristupi za hemodijalizu na autolognim krvnim sudovima ruku. U: Donfrid B, Dimković N, urednici. Sekundarni vaskularni pristupi za hemodijalizu. Monografije naučnih skupova AMN SLD 2018;8(2):41-58.

39. Shenoy S. Future Trends in Vascular Access Creation. Contrib Nephrol 2017;189:252-6.

40. Achneck HE, Sileshi B, Li M, Partington EJ, Peterson DA, Lawson JH. Surgical aspects and biological considerations of arteriovenous fistula placement. Semin Dial 2010;23(1):25-33.

\title{
Kasne postoperativne komplikacije arteriovenske fistule za hemodijalizu
}

\author{
Zlatko Maksimović ${ }^{1,2}$, Nenad Lalović2 ${ }^{2}$ Siniša Maksimović1,3 \\ 'JZU Bolnica "Sveti Vračevi" Bijeljina, Republika Srpska, Bosna i Hercegovina \\ ${ }^{2}$ Univerzitet u Istočnom Sarajevu, Medicinski fakultet, Foča, Republika Srpska, Bosna i Hercegovina \\ ${ }^{3}$ Univerzitet u Banjoj Luci, Medicinski fakultet, Banja Luka, Republika Srpska, Bosna i Hercegovina
}

\begin{abstract}
Vaskularni pristup je preduslov za izvođenje hemodijalize, ali su različite i česte komplikacije njihova "slaba tačka". Savremeni vodiči preporučuju nativnu arteriovensku fistulu (AVF) kao prvi izbor vaskularnog pristupa, jer je odlikuje najduže preživljavanje i najmanje komplikacija u odnosu na druge vaskularne pristupe. Sve komplikacije AVF mogu se podijeliti na intraoperativne, rane i kasne postoperativne. U ovom radu prikazane su kasne postoperativne komplikacije AVF, njihova učestalost, uzroci, dijagnostika i liječenje.
\end{abstract}

Najvažnije kasne postoperativne komplikacije su: stenoza, tromboza, formiranje aneurizme ili pseudoaneurizme, infekcija, edem ruke, hematom, ishemijski steal sindrom, ishemijska neuropatija, kongestivna srčana slabost. Velike razlike u učestalosti pojedinih komplikacija u dosadašnjim studijama mogu se objasniti razlikama u hirurškoj tehnici, lokalizaciji AVF, metodama dijagnostike ali, prije svega, razlikama između prikazanih grupa bolesnika. Opisano je da starost bolesnika, pol, osnovna bolest, prisustvo komorbidnih stanja i različitih metaboličkih i imunskih poremećaja karakterističnih za hroničnu insuficijenciju bubrega, kao i način korišćenja i njege AVF značajno utiču na pojavu komplikacija AVF. Jedan od glavnih prediktora uspjeha i preživljavanja AVF jeste kvalitet krvnih sudova bolesnika i zato je pažljivo ispitivanje krvnih sudova prije pristupa kreiranju AVF od posebnog značaja.

Kreiranje, korišćenje i njega AVF je zadatak tima zdravstvenih radnika koji učestvuju u liječenju ovih bolesnika, a za uspješno liječenje potrebna je njihova dobra saradnja, kao i saradnja sa bolesnicima.

Ključne riječi: arteriovenska fistula, hemodijaliza, kasne komplikacije, faktori rizika 